\title{
Effects of Forest Harvesting on Nitrogen- Cycling Processes in Headwaters of the Neversink River, New York
}

The upper Neversink River basin in the Catskill Mountains of New York contains about 92 square miles of sparsely settled, mostly forested land (fig. 1). The river drains into the Neversink Reservoir, one of six that supply drinking water to New York City from the Catskill Mountain region. The terrain is steep and contains some of the highest mountains in the Catskill region. The U.S. Geological Survey, in coopera- tion with the New York City Department of Environmental Protection, is studying the effects of forest harvesting on nitrogen-cycling processes in the Neversink watershed because of the potential effects on stream water quality.

The Catskill Mountain region has among the highest rates of atmospheric nitrogen deposition in the northeastern United States (Ollinger and others, 1993). This nitrogen falls in rain and snow as a dilute solution of nitric acid. As runoff moves down the steep slopes and through the thin soils, the acidity is only partly neutralized, and the accompanying nitrogen is readily transported as nitrate to streams. Long-term data (Murdoch and Stoddard, 1992) show that nitrate concentrations in Catskill streams have increased during the past 50 years (fig. 2), and that Catskill forests may be approaching a condition known

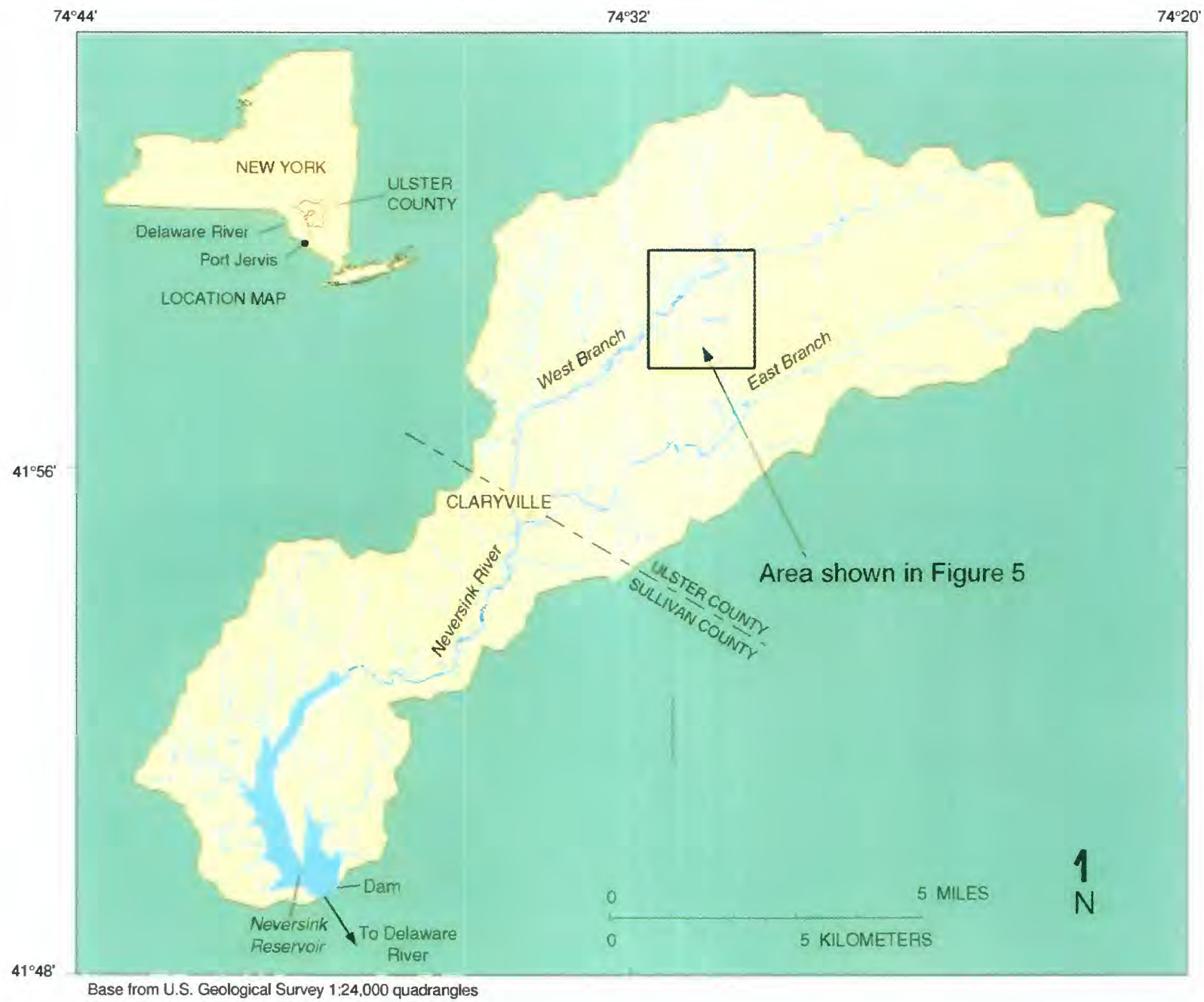

Figure 1. Location of the study area in the Neversink River watershed. 


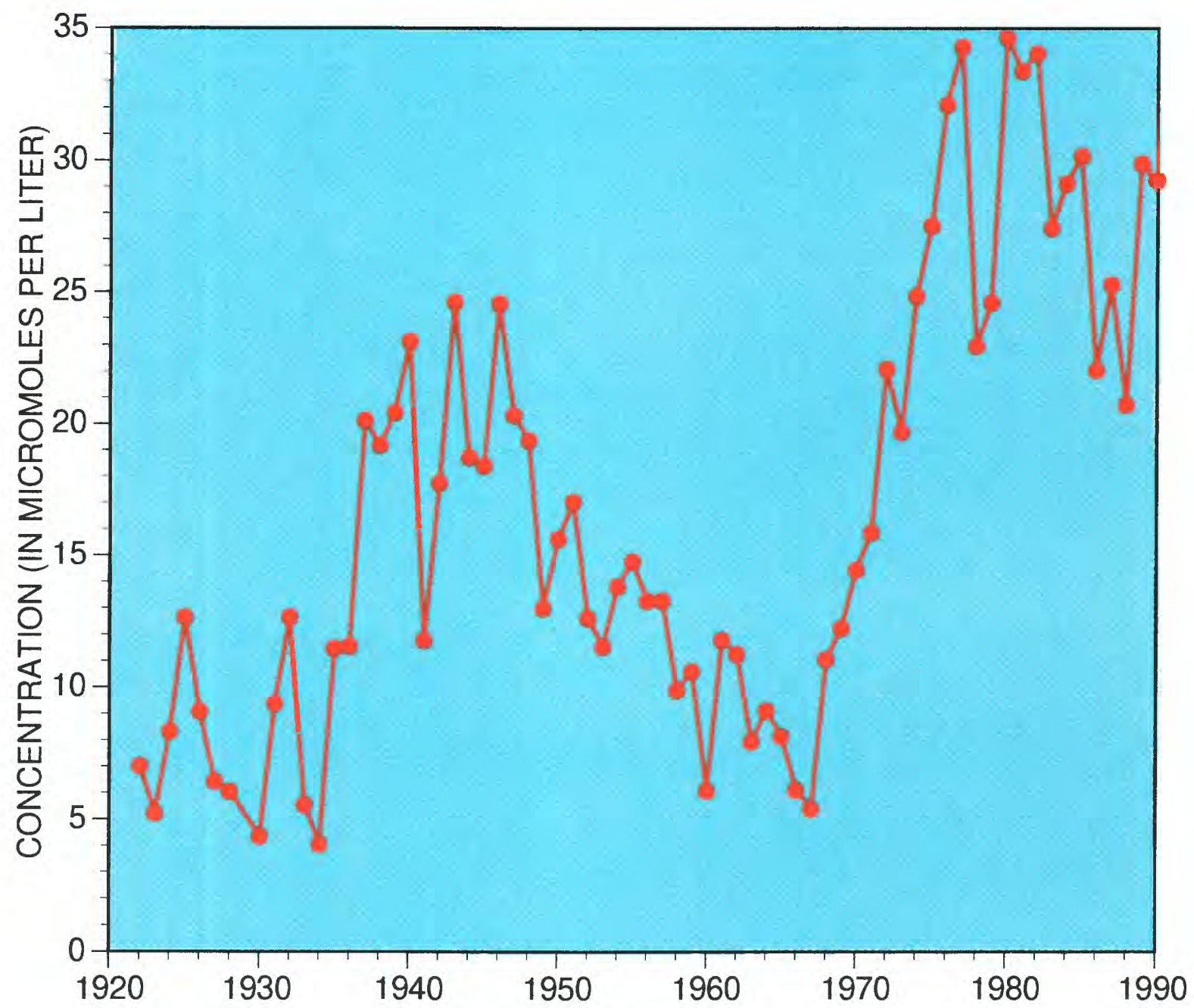

Figure 2. Mean annual nitrate concentrations in the Schoharie Creek near Prattsville, N.Y., based on samples collected and analyzed by the New York City Department of Environmental Protection.

as nitrogen saturation, in which the rate of atmospheric nitrogen deposition exceeds the biological demand for the nutrient. Thus far, the concentrations of nitrate in Catskill streams have been much lower than the U.S. Environmental Protection Agency drinking water standard of 714 micromoles per liter (U.S. Environmental Protection Agency, 1995); thus, nitrogen saturation is not expected to result in a direct threat to public health. Continued nitrogen deposition could, however, result in excess nitrate concentrations in streams sufficient to have deleterious effects on stream biota.

\section{How does forest harvesting affect nitrogen cycling and water quality?}

Most of the atmospherically deposited nitrogen in environments such as the Catskills is taken up by forest vegetation, and some additional nitrogen can be removed by microbial denitrification (fig. 3). Although large parts of the Catskills are State-owned wilderness in which forest harvesting is prohibited, some harvesting continues on private lands. Complete removal of trees from hardwood forests in other parts of the northeastern U.S. that are similar to the Catskills has been shown to cause increased concentrations of nitrate, acidity, and aluminum in streams and lakes for the first two years after the cut (fig. 4) (Hornbeck and others, 1987). These increases in nitrate concentrations were the result of increased rates of mineralization (conversion of organic nitrogen to ammonium by microbes) and nitrification (conversion of ammonium to nitrate by microbes), which occur when the forest canopy is removed, causing soil moisture and soil temperature to increase. Regeneration of vegetation two to three years after harvesting may cause nitrate leaching from soils to be lower than in comparable native forests. Forestry practices that minimize soil disturbance and leave some of the trees standing may reduce or eliminate these short-term changes in the nitrogen cycle. 


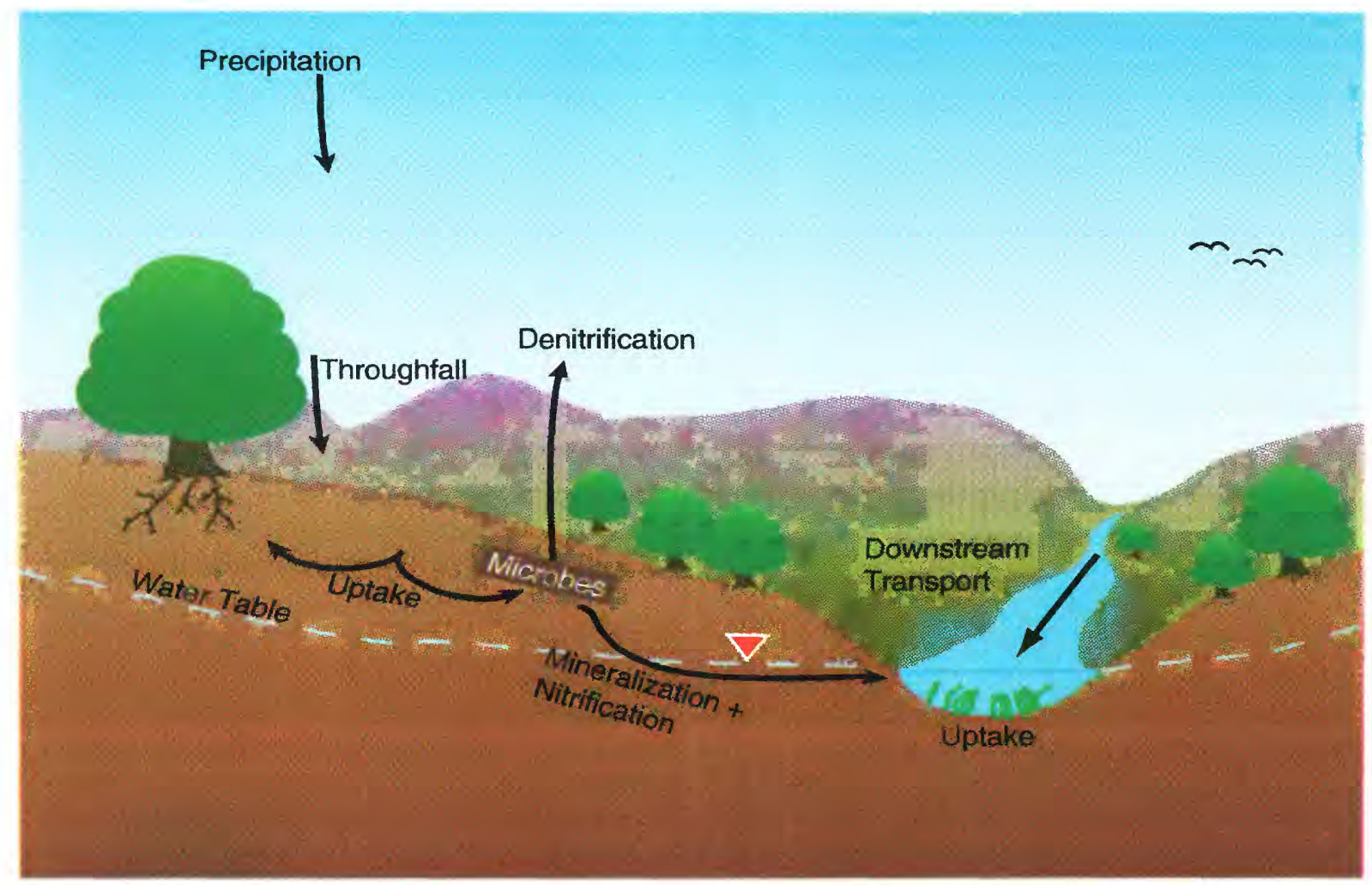

Figure 3. Idealized nitrogen cycle in a forested watershed showing the major processes that affect the transport of nitrogen to streams.

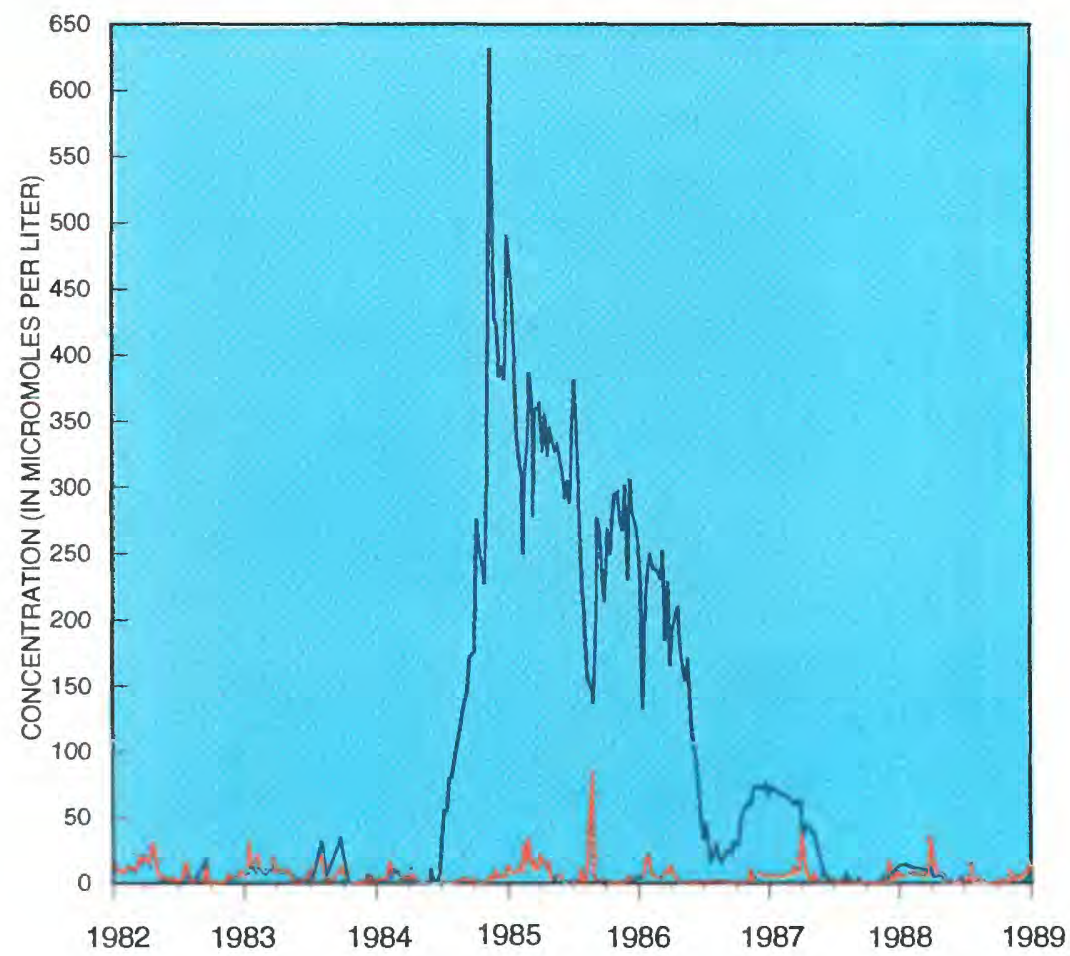

Figure 4. Monthly concentrations of nitrate in streams in watersheds 5 and 6 at the Hubbard Brook Experimental Forest in New Hampshire. All of the trees were removed from watershed 6 (dark blue line) in the winter of 1983-84. Watershed 5 (red line) remained undisturbed throughout the period.

\section{What Are The Objectives of The Study?}

The objectives of the study are to determine: (1) how two different forest harvesting techniques affect the rates at which nitrogen and related chemical constituents are processed within two Catskill watersheds, (2) the implications of changes in nitrogen-cycling rates on stream-water quality and stream biota, and (3) how fast and to what extent nitrogen retention in the affected watersheds recovers from the effects of harvesting.

\section{How Will The Work Be Done?}

Three tributary watersheds of the West Branch Neversink River (fig. 5) have been chosen for study. One watershed will remain undisturbed, the second will have about 40 percent of its trees removed (called a timber-stand improvement cut), and the third will have all of its trees removed (fig. 5). Streamflow and stream 
chemistry will be monitored for an 8-year period encompassing the preharvesting period, the two-year harvesting period, and the first four years after harvesting. Soilwater chemistry, nitrification rates, and effects on stream biota will also be studied. The sites serve as a field laboratory in which the effects of disturbance on a variety of processes can be measured. Additional studies of vegetation, sediment transport, and hydrology are being carried out by other agencies and universities. The study is being conducted on lands owned by the Frost Valley YMCA, who are removing the vegetation necessary to complete the study, and utilizing the watersheds in their environmental education program.

\section{What Information Will This Study Provide For Watershed Managers?}

Watershed managers need data on the effects of disturbance and the rates of recovery to make decisions pertaining to forest harvesting in the Catskills. Data from this study will allow comparison of the effects of clearcutting and timberstand-improvement practices on nitrogencycling rates, stream-water quality, and stream biota. The multidisciplinary nature of this and related studies at the site will provide the hydrologic, biologic, and aquatic chemical data needed for a thorough assessment of the effects of forest harvesting, acidic deposition, and climate on forested ecosystems in the Catskills.

—Douglas A. Burns, Natalie K. Karouna, and Peter S. Murdoch

\section{ACKNOWLEDGMENTS}

Thanks are extended to staff from the U.S. Forest Service in Malvern, Pennsylvania for assisting with the installation of game fence along watershed boundaries, and to the U.S. Forest Service in Durham, N.H. for the use of data from the Hubbard Brook Ecosystem Study.

\section{REFERENCES}

Hornbeck, J.W., Martin, C.W., Pierce, R.S., Bormann, F.H., Likens, G.E., and Eaton, J.S., 1987, The northern hardwood forest ecosystem: Ten years of recovery from clearcutting: USDA Forest Service Northeastern Forest Experiment Station, NE-RP. 596, Broomall, $\mathrm{Pa}$., 30 p.

Murdoch, P.S. and Stoddard, J.L., 1992, The role of nitrate in the acidification of streams in the Catskill Mountains of New York: Water Resources Research, v. 28, p. 2707-2720.

Ollinger, S.V., Aber, J.D., Lovett, G.M., Millham, S.E., Lanthrop, R.G., and Ellis, J.M., 1993, A spatial model of atmospheric deposition for the north- eastern U.S.: Ecological Applications, v. 3, p. 459-472.

U.S. Environmental Protection Agency, 1995, Drinking water regulations and health advisories: Washington, D.C., Office of Water, U.S. Environmental Protection Agency, 11 p.

\section{For more information contact:}

\section{District Chief \\ U.S. Geological Survey \\ 425 Jordan Road \\ Troy, New York 12180 \\ (518) 285-5602}

USGS Water Resources of the United States http://water.usgs.gov

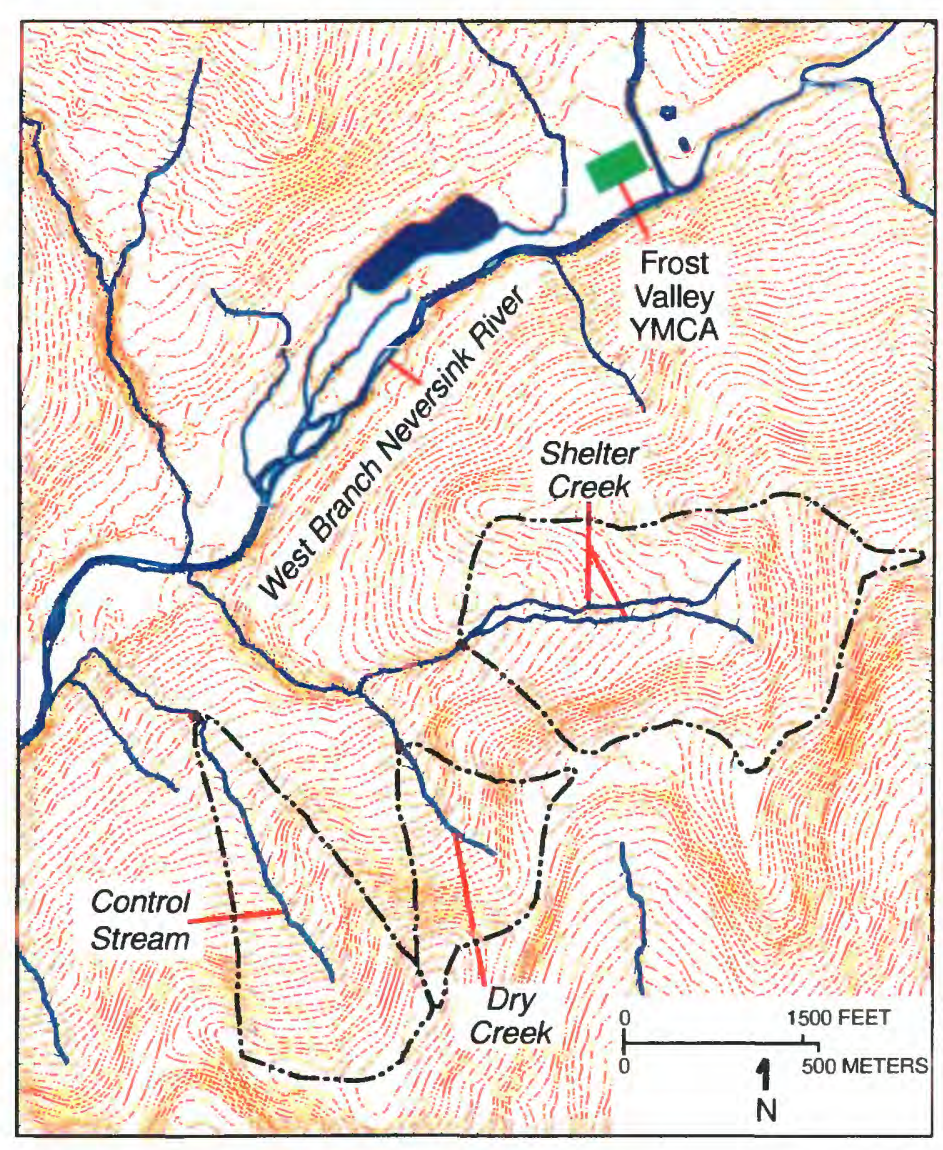

Figure 5. Locations of the three watersheds to be studied, showing the watershed from which 40 percent of the trees will be removed (Shelter Creek), the watershed from which all trees will be removed (Dry Creek), and the watershed that will remain undisturbed (Control Stream). 